\title{
The Teaching Reform in Oral English for Non-English Majors Based on FIF
}

\author{
WANG Bing \\ Leshan Normal University, Leshan, China
}

\begin{abstract}
Nowadays the oral English levels of non-English majors in colleges do not live up to the expectations from the all walks of life. Due to the rapid development of the communication technology, many cell phone apps about the English learning have appeared. So this paper tries to put forward some effective ways to reform the oral English teaching for non-English majors based on FIF-a cell phone app about oral English learning after analyzing the status quo of current oral English teaching and learning and the advantages of FIF.
\end{abstract}

Keywords: teaching reform, oral English, non-English majors, FIF

\section{Introduction}

With the development of the economic globalization, English, as a major language, has become increasingly important. The college English education, as the main medium, has played a vital role in improving national English skills. Besides the English majors, most of the non-English majors in colleges have greatly developed their English abilities in listening, writing, and reading. They can understand their favorite songs and the news on TV, gather the useful information from the English newspapers or magazines to help their studies, or even write academic papers in English to express the different ideas in their fields. But the relatively poor English speaking ability hinders their further development. As the basic communication tool, their oral English must be improved in order to be more deeply involved in the international cooperation and competition. Thanks to the development of the communication industry and IT (Information Technology) industry, cell phone apps about English learning provide us with the opportunities to conduct some reforms in the oral English for non-English majors. This is urgent after considering the status quo of current oral English teaching and learning in colleges.

\section{The Status Quo of Current Oral English Teaching and Learning}

\section{The Poor Mastery of English Basics}

Although college students have been learning English for six to seven years, it is also a common phenomenon that their English vocabulary is very narrow and they often make some grammatical mistakes. Their English pronunciation is not correct. The tone and intonation are not up to the standard. Even sometimes the English sentences are made in the way we make the Chinese sentences (CHEN, 2011). That is what we call "Chinglish" which sounds very unnatural even strange to the foreigners.

WANG Bing, lecturer, M.A., School of Foreign Language, Leshan Normal University, Leshan, Sichuan, China. 


\section{Lack of Confidence in Oral English}

Because much attention has been paid to the input of knowledge in class and due to lack of output, besides the non-English major's poor vocabulary, pronunciation, tones, and intonations, they have little confidence in the oral English. They do not dare to speak their minds in English in case they make some mistakes because they care about the phonetic exactness, the correctness of word selection, and the grammatical usage (YUE \& LI, 2012). Particularly when they make these mistakes, they are shamed to do so next time for the fear that they should be laughed at by others. Gradually they become less and less confident of their oral English. In addition, most of Chinese students are more introverted and are unwilling to communicate with others in class about their minds and thoughts, let alone communicate with strangers. Without practice, their oral English cannot be improved.

\section{The Low Initiative in Oral English Practice}

Influenced by the traditional oral English teaching beliefs, current oral English teaching presents several disadvantages: (1) the boring teaching contents. Nowadays some of the teaching contents are still the ones 20 year ago. Obviously they are out of date; (2) the inappropriate topics. College students today are totally different from those 20 years even 10 years ago. They have experienced the great development in the IT and communication industries. They are more likely to be active in their mind and pay more attention to the hot topics or issues on the Internet or social media through which they like to express themselves better. More importantly, they are inclined to use their cell phones to communicate with others, not through the traditional face-to-face talk. So the teaching topics should include the controversial topics that they are concerned about on the Internet or social media to arouse their interests, not just the traditional topics about moral teachings; (3) the one-fold teaching mode. The teaching mode should be diversified instead of just making students deliver speeches. It should include the debates, musical shows, dramas, etc., that the students are willing to participate in. In the process, teachers should play the guiding role actively in the class, pointing out the mistakes after the performances and the ways to improve the oral English. All the three points mentioned above can result in the student's lack of motivation to practise their oral English.

\section{The Classroom as the Only Medium to Have the Oral English Teaching}

The non-English majors rely too much on the teaching in the classroom, which is the obstacle to improving their oral English. After all, the teaching time in the classroom is limited, so are the chances and resources given to them to practice their oral English in view of the number of students in each class. There are at least 40 students in each class. So the teachers should help students to create the "Second Class". That means after class, the students should take advantage of every opportunity to practise the oral English, for example, they can find partners in daily life, or organize the speech competitions among the classmates, or even communicate with teachers in English through cell phone apps, etc. In all, the teacher should not restrict their teaching only in the classroom.

\section{Little Emphasis on Oral English From School Authorities}

In many colleges and universities, little importance is attached to the oral English. Especially for the non-English majors, the basic courses of College English consist of intensive reading course and listening and speaking course. But because in the former one, there are too many language points including considerable amount of vocabulary and grammar knowledge, it has been paid much attention. Non-English majors deem it 
more important and applicable. They can gain the knowledge and obtain the good grade while the latter one is believed to be in an embarrassing condition because of the limitation of the teaching facilities and the scale of the class. Many students think the listening and speaking course should be cut out due to the little time left for practice in class. As a result, their oral English cannot be improved. In addition, the reasonable and standard grading rules and regulations for the oral English have not been carried out in many colleges and universities, which is the current situation for oral English.

\section{The Advantages of FIF}

FIF is a kind of Cloud Learning platform created by an educational and technological company in Beijing, which can provide many kinds of resources online about English learning including the oral English training. It can be accessed from the Internet through PC or the app installed in the cell phones. We concentrate on the function of oral English training, although there are many other functions, such as the tests, the class management, etc. Altogether FIF can produce several advantages to the oral English training over the traditional teaching in the classroom.

\section{To Arouse the Student's Interests in Oral English}

It seems that we are now in the age of cell phones. Everybody appears to be so dependent on it. Especially the college students like it better. They chat with friends, update their microblogs, watch the TV series or movies, or even do their homework through cell phones. In view of this, FIF tries to arouse the student's interest in oral English in the following ways: (1) easy to use. The students who want to practise the oral English just need to download an app and apply for a user's name and a password. It will not cost too much time. When they do the practice, they just need to imitate what has been said for them from a speaker designed by the system. Furthermore, if they are confident of their oral English, they can take the challenge pattern (See Picture $1 \& 2$ ). That means you cannot practise next one until you finish the previous sentences or paragraphs with a certain score. It is just like a game. You can only meet with the ultimate boss after you finish all the minor ones; (2) the quick feedback. The score will be given immediately after each sentence or short paragraph has been practised. This is a significant difference from the traditional oral English test. What is more, it is more objective. The traditional oral English test in the college is usually conducted by an English teacher whose scores may not be so objective, which will frustrate the student's learning interest to a certain extent. In contrast, the students may choose to believe the scores given by the machine. Furthermore, if the student can witness the improvement by themselves little by little, they will gradually acquire the confidence in the oral English from it, which is most important.

\section{To Cater to the Needs of Most Students}

The college students' oral English levels vary from person to person due to their respectively different learning backgrounds when they are in high schools before they enter the college. For example, some students in urban high schools can speak fluent and standard English because of the advanced facilities and qualified staff while others in the rural areas even cannot pronounce the single word well. Maybe the English teachers there themselves cannot speak the standard English, let alone their students. Therefore here in college, these two kinds of students have different goals in the oral English learning. Given the situation, FIF provides them with different learning contents with different levels. The former one can choose the contents suitable for them, such as the oral English of TOEFL (The Test of English as a Foreign Language) which is spoken by the natives. 
The latter can choose to start from phonetics, words, phrases to sentences (See Picture 3). Thus, the teacher can achieve the aim of teaching the students in accordance with their aptitudes.

\section{To Monitor the Student's Learning Activity}

Another powerful function of FIF is that it can help the teachers to monitor the student's learning activity. The teachers can assign some tasks for the students to accomplish within a time limit through FIF (teacher's edition). Every student can do the task through FIF (student's edition). It goes like this: When the students receive the task. There are several units, each of which may include several sentences or short paragraphs about a topic. The students just need try to imitate the speaking of them given by the designed speakers. All the speaking by the students will be recorded. The scores will be given after they finish the each imitation immediately. In the end, an overall score will be given according to the student's performance. This score and all the speaking can be sent to the teacher's edition of FIF. So the teacher can hear what the students have spoken and give the proper guidance accordingly. Furthermore, they can know which student has not carried out the practice or which one falls behind others in the practice within the time limit. Thus the teacher can remind them to take part in or to quicken the process. Only in this way will the function of monitoring the student's leaning activity be realized.

\section{To Keep Track of the Student's Performances}

The function of keeping track of students' improvement is extended form the one mentioned above. Since FIF can give an overall score to the student's speaking in each task, the teacher can keep track of the student's performances by observing the score tendency among 10 to 20 tasks on the premise that the difficulty levels are almost the same in these tasks. If the score tendency is from low to high, it must be certain that the student's oral English has been improved and it will bring more confidence to him and he will achieve more. It is a virtuous cycle. Vice versa, if the score tendency is from high to low, the teacher must find out the reasons for this to help the student, otherwise it will be a vicious circle.

\section{The Effective Ways to Reform Oral English Teaching Based on FIF}

\section{To Introduce FIF Into the Class as a Teaching Tool}

Compared with the traditional oral English teaching method which is outdated and unsuitable for the college students living in the information age, the usage of FIF in the classroom as a tool for the oral English teaching definitely will arouse the students' interests and initiatives in the oral English because of its rich training resources which are closely relevant to the college life of their own and the English study. For example, there are some training materials about the social activities on campus like debates, elections, matches, exams, job interviews, etc. The oral English trainings about TOEFL and IELTS (International English Language Testing System) are also included. Furthermore, the teacher can create the training materials that the students may be interested in. So teachers should take advantage of FIF in the classroom to assist in the students' oral English learning. For example, in the classroom, the teacher can select a topic for the students to practise. The teacher can rectify their pronunciations, tones, and intonations while they are practising. After that, the teacher can organize a debate or a role play for them to utilize the English expressions they have practised. As long as the teachers can put their hearts into it, the students' oral English surely will be improved.

\section{To Establish the Partnership Among Students After Class}

Although it is helpful to use FIF as a training tool in the classroom, the training time in the classroom is 
limited. When the teachers have assigned some training tasks for the students after class, it seems especially important that the students can take the initiative to conduct the training tasks (ZHAO, 2014). But some students may forget the assignment due to various reasons, so it is necessary to establish the partnership between students. They can remind each other of the tasks after class. That means they have more opportunity to practise their oral English. Although teachers can monitor the students' performances, including their scores, the times they take part in the practice, etc., the chance for practice has slipped. The only thing teachers can do is to remind them to participate in the practice next time because there is a time limit for the practice every time. So it is wise to establish the partnership between students to monitor each other to prevent the phenomenon from happening (ZHU, 2005).

\section{To Construct the Reasonable Assessment System for Oral English Teaching and Learning}

The traditional assessment system for oral English teaching is out of date because it is hard to evaluate a teacher only through watching one of his teachings in the classroom. The scores given by the experts or colleagues cannot reflect the truth about the teaching because improving the student's oral English is a dynamic process. So the assessment should be dynamic too. If the student's oral English is improved compared with that a year ago, a month ago, or even a week ago, we can say the teacher is successful in teaching oral English. Equally it applies to the assessment of students' oral English learning. We cannot judge a student's oral English just through an oral English test in the final exam. We should take into account his daily performances through FIF. Is he active in practising the oral English? How many times has he participated in the practice? What is his average score? We can get all these statistics in FIF. Besides it, the final oral English test should be based on FIF. For example, we can select a topic that they have practised before for the students to give a speech or to have a debate, etc. If they can fluently express themselves, we should make a positive comment or judgment. In all, we should evaluate the oral English teaching and learning in a dynamic way.

\section{Conclusion}

Although the status quo of oral English teaching and learning is not satisfactory because of many factors, we can find some ways to change it. Compared with the traditional oral English teaching methods, FIF, a kind of Cloud Learning platform, has many advantages, such as the convenience for the teachers and students, its fitness for all the students, its easy manipulation, etc. Based on FIF, we can take effective measures to improve students' oral English, for example, FIF can be used as a teaching tool in the classroom and a test tool in the final exam. Most importantly, students can make use of it in their daily life to practise the oral English whenever they want just as a saying goes "Practice makes perfect". I believe as long as the students stick to the practice, their oral English will be enhanced, so will the teaching reform in oral English based on FIF.

\section{References}

CHEN, L. F. (2011). A survey and discussion on oral English proficiency of non-English majors. Fuqing: Journal of Fuqing Branch of Fujian Normal University.

YUE, C., \& LI, S. Y. (2012). The analysis of status quo of college oral English teaching and the teaching methods. Beijing: China Science and Technology Information.

ZHAO, W. C. (2014). Application of flipped classroom in college oral English teaching. Anshun: Journal of Anshun University.

ZHU, X. (2005). The application of extracurricular monitoring mechanism in college oral English teaching. Shanghai: Foreign Language World. 
Appendix: Some pictures about FIF

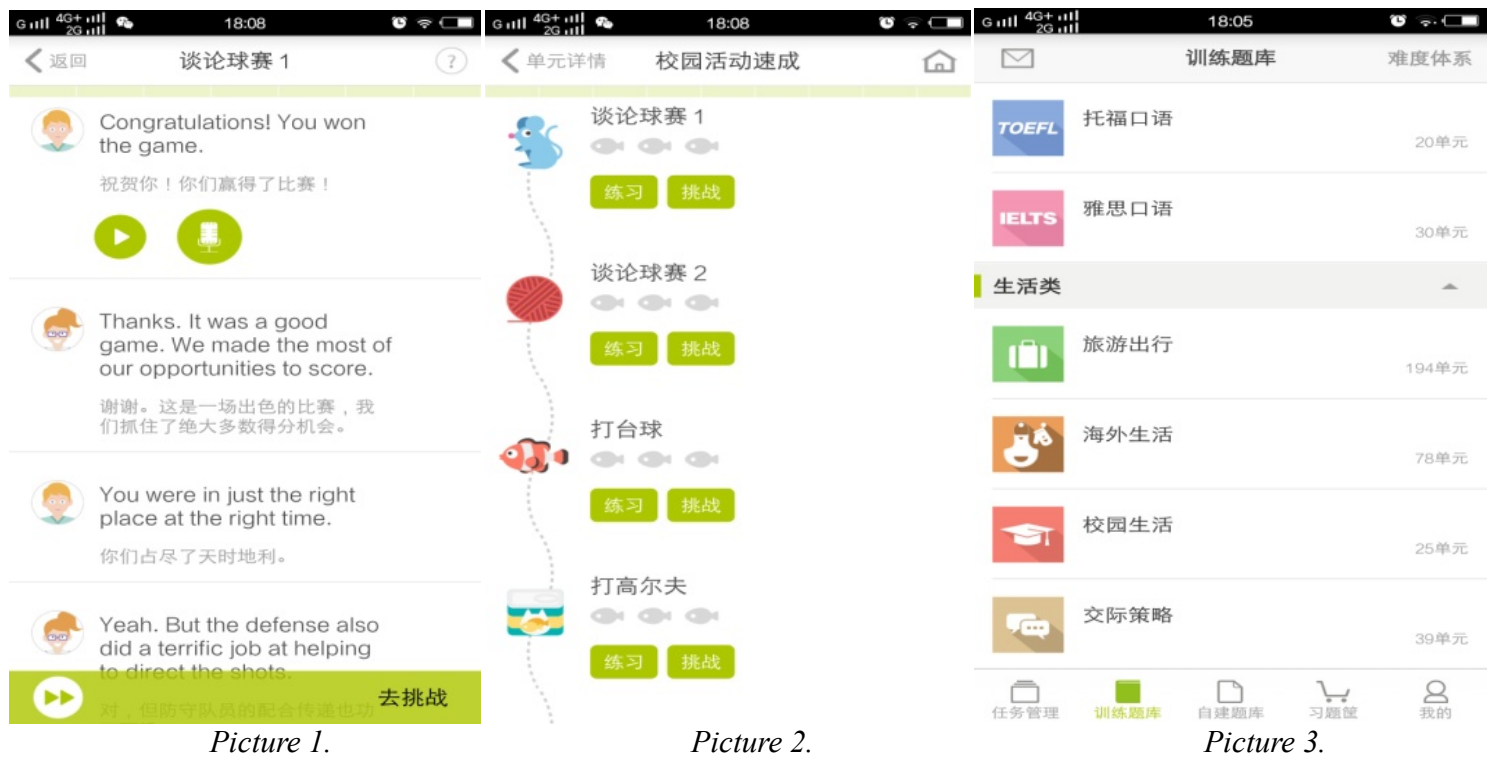

